\title{
The Patisserie Project Based Learning Model to Enhance Vocational Students' Generic Green Skills
}

\author{
Ana, ${ }^{\text {a,1, }}$, Sri Subekti ${ }^{\text {a }}$ Siti Hamidah ${ }^{\text {b }}$ \\ ${ }^{a}$ Home Economics Department, Technical and Vocational Education Faculty \\ Indonesia University of Education, Bandung, INDONESIA \\ ${ }^{\text {b}}$ Yogyakarta State of University, Yogyakarta, INDONESIA \\ 1 ana_syarief@yahoo.co.id
}

\begin{abstract}
Characteristic of patisserie learning is very different to other culinary expertise learning. To obtain maximum results, the patisserie learning process need to be designed and developed based on a particular model and approach, so that it has a clear foundation, both conceptually and operationally. The objectives of the research were to: develop model of Patisserie learning based project to improve generic green skills vocational students', and produce learning tools such as lesson plans, manual of patisserie project based learning model. Delphi Technique is used to assess learning tools. To measure level of inter-rater reliability of the model and its classroom implementation, percentages of agreements (PoA) are used. Data collection techniques employed in the study are questionnaire validation sheets. The results shows that teaching and learning tools of Patisserie based on project can be used in patisserie learning, with a fairly high level of agreement.
\end{abstract}

Index Terms - patisserie, patisserie project-based learning model

\section{Introduction}

Patisserie is the most advanced field in the culinary world. In America, patisserie has a very vital role in supporting the success of restaurant and other food businesses. The extensive patisserie business opportunities in the world, especially in Indonesia, are therefore calling for special patisserie expertise. Today, the field of patisserie has undergone rapid development in processing techniques, shapes varieties, decoration, delivery and packaging. Its growth is collaterally with developments of business world, especially culinary business. Jacques Torres [1],pastry chef at Le Cirque France, stated that there has been a lot of evolution in the field of patisserie in the last 10 years, including new techniques, materials and art of delivering patisserie products. These indicate that the patisserie field demands high adaptability and, thus, requires efforts to align its learning process in intitutions with work field and business needs.

One study in culinary expertise is patisserie, which is an important element in its learning. Patisserie itself is a term derived from French language, which talks about manufacture of pastry and cakes, both sweet and salty taste. In national curriculum, patisserie becomes a course focusing on students' ability to understand the characteristics, materials and formulations of patisserie products, as well as to be skilled and creative in manufacturing process, from planning through finishing the products. During the learning process, the students are required to work collaboratively in groups to create product planning, from the beginning until the end of production process. Therefore, it is obligatory for the students to have integrated capabilities, including disciplines, skills, and other task completion soft skills.

Characteristic of patisserie learning is very different to other culinary expertise learning. In patisserie, the students should follow carefully all procedures of making a product, starting from materials selection, material formulation, materials weighing, processing methods, production procedures, and appropriate packaging. The products cannot be corrected during the process. So if there are errors in the beginning, it can be ascertained that the resulting product does not comply with product standards. Processing methods used in patisserie are very typical, specifically in the techniques, equipment used, baking temperature, decoration, packaging and other treatments. In addition, the learning process includes a variety of problem-solving ability. The students are required to be able to analyze in depth all issues related to patisserie products. This is one of challenges in studying patisserie.

To obtain maximum results, the patisserie learning process need to be designed and developed based on a particular model and approach, so that it has a clear foundation, both conceptually and operationally. The presence of project-based learning model in patisserie learning is expected to improve the quality of the course, reduce the gap between the demands on the curriculum and the ability of lecturers, and avoid the lecturers from speculating on evaluation and assessment process or the use of learning methods. Theoretically, the project-based learning model has a number of advantages in overcoming the problems referred above.

The effectiveness of project based learning was evidently supported by research. It was shown that project based learning can improve various competences such as academic achievement, high thinking level, a better critical thinking skill, problem solving ability, creativity, independence, the ability of viewing a situation from a better perspective, a deeper understanding of learning material, more positive attitude towards a study, more positive and supportive relationship among peers, flexibility in communication, and learning motivation [2] [3] [4] [5] [6] [7]. The project-based learning is also one of models that support the use of student centered learning (SCL), which is now a challenge for the implementation of learning process in college.

The study is expected to help overcoming the lecturers' limitation in implementing learning strategies during 
learning process. Not only as a measure to reduce the limitations, the development of this model also aims to validate further the development of similar teaching model. Patisserie learning model development, at least, provides insight that learning management, materials, methods, media and assessment are all an integral part. The study also gives feedback to the lecturers to implement a more meaningful learning process, as appropriate learning strategies and assessment will educate students to be more sensitive to scientific ideas, concepts and procedures. Thus, in the long run this condition will yield future academic success..

\section{Methods}

In assessing the model and teaching and learning tools, expert judgment was used through Delphi technique. The Delphi technique is a way to organize the experts' ideas in order to fix future situation. In this technique, varying opinions of people with relevant interest may be collected, looked for point of agreements and summarized as a consensus to define a particular purpose. One of Delphi's purposes, as stated by Dalkey [8] is to search for information that can generalize consensus in respondents group. The use of the Delphi technique in this study is to obtain unanimity of experts and practitioners on the design of developed patisserie project-based learning model.

To measure the level of inter-rater reliability of the model and its classroom implementation the percentages of agreements [9] were used.

To calculate the percentages of agreements between assessors whose data are only yes or no, a formula proposed by Grinnell [9] was then used as follows:

percentages of agreements $=\frac{\text { Agrements }}{\text { (Disagrements }+ \text { Agresments }} \times 100 \%$

Lower limit of good reliability coefficient, that is 0.70 [10].

The primary data collection technique employed in the study is questionnaire validation sheet. There were three education experts (on curriculum and culinary) who conducted assessment on the model and learning tools such as lesson plans, manual of patisserie project based learning model (cake, choux paste, and puff and danish pastry). The aspects that were assessed were its content and language. Assessment criteria used were Likert scale with four scale levels as follow: 4= Very good, 3 = Good, 2 = Barely acceptable and $1=$ Poor. The three observers used observation sheet to examine the model process conducted by lecturers; the observation sheet contains yes or no questions.

\section{Result and Discussions}

Nowadays, higher education should support the students to develop specific expertise and knowledge in the discipline chosen and also facilitate them to develop 'the skills necessary for employment and real life as a responsible citizen' .In the context of group learning, students are facilitated to develop key skills (generic green skills) such as communication, problem solving and teamwork. Students can only become proficient in a skill by practicing it. In the context of group learning, the students have to learn how to work within a group and listen and negotiate with others in order to resolve dilemmas or conflicts.

The fundamental concept of patisserie project-based learning model is the importance of equipping students with generic green skill. Based on literature review, the development of patisserie project-based learning model refers to production model of Oakey [11] Sharan [7] and Han [12]. The lecture who wants to employ this model, firstly should understand the characteristics of project based learning, the competences developed, the learning strategies, and the teacher's roles. Here is the operational view of patisserie project-based learning development design:

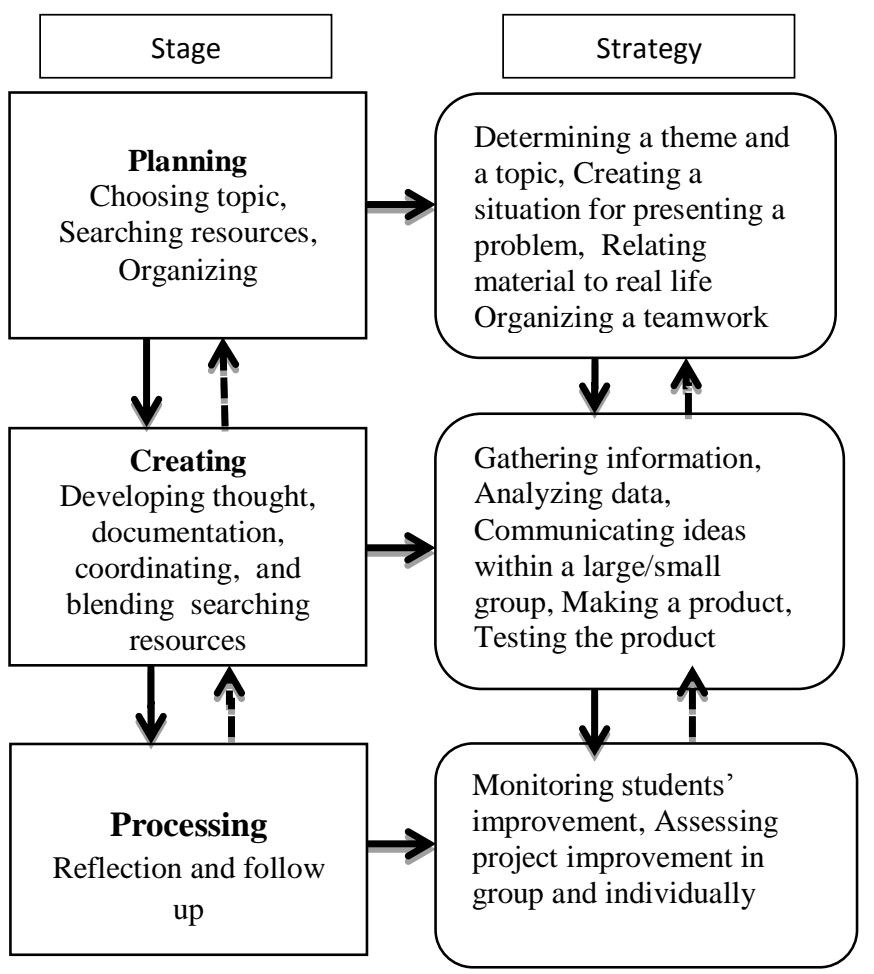

Fig 1 The Patisserie Project Based Learning Model (production approach)

According to Figure 1, Patisserie project-based learning model can be explained as follows: Learning procedures are three stage, planning, creating, and processing.

a. Planning: Lecturer explains learning contents, learning results, learning media such as learning guide log book, learning resources, and assessment.

b. Creating :

1) Lecturer informs cake and pastry development principles, development of cake and pastry variation, and patisserie business planning.

2) Lecturer provides various topics to be chosen by students in group. She delivers an assignment based on the topic chosen. The topics relate to real problems.

3) Lecturer explains cake and pastry development, business planning principles, and activity design of cake and pastry development project.

4) Students choose a topic and determine the objective of final product making. In this stage, lecturer organizes class, grouping, and learning resources, and assigns work and activity schedule. 
5) Students are given a chance to take a full responsibility by collaborating with peers in their project accomplishment.

While class activities student have 3 part activities are: exploration, interpretation and creation.

6) Exploration part. Students examine the topic that they choose and explore many learning resources which are relevant to the topic/concept/problem investigated. In this stage students get guidance to discover problems in real world. Lecturer asks students to find an alternative and formulate a strategy of problem solving.

7) Interpretation part. In this phase, the exploration result is interpreted through the activity of analysis, discussion, and question and answer. Students are encouraged to discover the concept being examined through an interpretation by many ways such as observation, discussion, or demonstration of cake and pastry product making.

8) Creation part. Students are guided to designing. Each work group gets guidance to develop their product. They analyze and calculate the materials and formulate production procedure by using other supported tools. Lecturer guides students to accomplish the task that has been designed in the previous stage. Students are guided to make their product. The project activities in this phase involve many work types which are possibly done in parallel.

c. Processing : Reflection and feedback. Students review what they have been done and found during the learning process. They also receive suggestions and do correction to improve quality of the product they made. Student project accomplishment presentation and assessment activities.

The results of model evaluation by experts and practitioners indicate that the model is good and can be used with no revisions to the $2^{\text {nd }}$ phase model evaluation. The prerequisite referred is standard and communicative language, theory conformity, and constructed syntax, which has composed of the underlying principles.

Summary of the assessment of model by the rater (assessor) are appears that all the three assessors provide good scores for all aspects assessed. By then, the general assessment in this model validation stage can be used with little revision. However, after being revised, all the assessors state that the model can be used without revision

Table 1 Coefficient of Reliability the Percentages of Agreements in Evaluation Model

\begin{tabular}{llccl}
\hline No & $\begin{array}{c}\text { Assessment } \\
\text { Time }\end{array}$ & $\begin{array}{c}\text { Coefficient } \\
P o A\end{array}$ & Criteria & Description \\
\hline 1 & Stage 1 & 0,77 & $>0,70$ & Reliable \\
2 & Stage 2 & 0,80 & $>0,70$ & Reliable \\
& Average of & 0,785 & $>0,70$ & Reliable \\
& Coefficient & & & \\
& $P o A$ & & & \\
\hline
\end{tabular}

Level of reliability of the three assessors in providing the assessment can be explained by calculating the coefficient of reliability using the percentages of agreements (PoA) and comparing the results with the minimum criteria. It is said to be reliable if the coefficient PoA is $>0.70$. The reliability is calculated by computing the average inter-rater reliability coefficient. Summary of calculation results are presented in Table 1. As shown in Table 1, the assessor reliability in assessing model for two times has met all the prerequisites for reliability coefficient.

Competence achievement indicators students have trough this model students are: 1) able to understand the context of problem in which knowledge and skills are used for solving problems, 2) able to apply academic knowledge to the making of product needed on the market, 3) able to organize learning resources such as literatures, sources, etc., 4) able to design project activities, 5) skilled at designing a product, calculating materials and cost, planning a business by determining selling price, and making a time table and job order, 6) able to aplly academic knowledge to the practice of product making, 7) Students are creative at developing a product 8) skilled in the process of product making, 9) skilled at building a teamwork, 10) able to evaluate their own project resuls and 11) skilled at communicating their project results clearly.

\section{Conclusion}

Project-based learning model with production approach based on expert assessment might develop student's generic green skills in patisserie as it more emphasizes on the development of project management ability, collaboration ability, creativity and problem solving ability. The learning syntax of project-based learning model with production approach is arranged based on of project-based patisserie learning namely planning, creating, and processing. The learning model of project-based learning through validation stage by experts with high reliability level.

\section{Acknowledgment}

The authors would like to thank the Directorate of Higher-Education, Ministry of Education and Culture of the Republic Indonesia, which has provided funding of this research.

\section{References}

[1] MacLauchlan, Adrew. (1999). The Making Pastry Chef ; Recipes and Inspiration from America's Best Pastry Chefs, New York, John Willey \& Sons, Inc.

[2] Ana, Luthfiyah N. (2012). Development Model of Patisserie ProjectBased Learning. Journal Technical Education and Training UTHM Malaysia. JTET UTHM Malaysia Vol 4, No 2. ISSN 2229-8932

[3] Ana. (2008). Project Based Learning: Alternative of Teaching and Learning Model for Pre-service Teacher Education in TVET, International Journal of Education Vol.2 No.2, May 2008.

[4] Felder, R.M. \& Brent, R. (1996). Navigating the Bumpy Road to Student-Centered Instruction, College Teaching, 44, 43-47.

[5] Jaques, D.(2000). "Learning in Groups ( $3^{\text {rd }}$ ed.)”, London, Kogan Page.

[6] Thomas, J.W. (2000). A Review of Research on Project-Based Learning, California: The Autodesk Foundation, Derived on 5 November 2007 from: http://www.autodesk.com/foundation

[7] Sharan, Y.."Enriching the Group and Investigation in the Intercultural Classroom", European Journal of Intercultural Studies 9(2), 1998, 133-140

[8] Fazio,L.S. (1987). The Delphi: Education and Assessment in Institutional Goal Setting: David S. Cordray \& Mark W. Lipsey 
(Eds), Evaluation Studies: Review Annual, 11(pp.287-297), California, Sage Publications, Inc.

[9] Grinnel, Jr.M. (1988). Social Work Research and Evaluation. Third Edition. Illionis: F.E.Peacock Publishers, Inc.

[10] Linn, R.L. (1989). Educational Measurement. ( $3^{\text {rd }}$ ed.).New York : Macmillan Publishing Company.

[11] Han, S \& Bhattacharya, K. (2008). Constructionism, Learning by Design, and Project Based Learning. Derived on 23 Juli 2014 from http://www.edutopia/projects.coe.uga.edu.htm.

[12] Oakey, J. (1998). Project-Based and Problem-Based: The Same or Different?: http://pblmm.k12.us/PBLGuide/PBL\&PBL.html 